\title{
Utilization of Karyotypic Analysis of C- Banded of Egyptian Clover Chromosomes and Karyotype Characterization of Fixed Isolation Distances
}

\author{
BondokT.A ${ }^{1}$, Shereen M. EL Nahrawy ${ }^{1}$
}

\begin{abstract}
The present study was carried out to study the karyotype characterization of berseem Serw 1 cultivar as male parent and Gemmiza 1 cultivar as female parent, using the satellite chromosomes in Serw 1 as a marker to find out the accurate isolation distances in Gemmiza 1 as female parent, and their first generations polycrosses along 50,100,150 and 200 meter distances from the male parent cultivars (Serw1). The satellites chromsoms were previously found in Serw 1, where Gemmizal has not satellite chromosoms. Satellite chromosoms were not found in the first generations of (Gemmiza $1 \times$ Serw 1) which planted in $100,150,200 \mathrm{~m}$ away from the male parent Serw 1, but the satellite chromosomes were found as a markers in the segregated generations of the polycrossed via 50 meter distance (Chromosome number 4 SAT).
\end{abstract}

Also, C - banding technique was used to indentify the parental chromosomes of Serw 1 , Gemmizal and the resulted generations to confirm for how long the pollen grains of Serw 1 could be transfered under the open pollinated conditions for first generation polycrosses along $50,100,150$ and 200 meter distances.

In the present study, changes in the chromosomal characterization were detected that indicating pollen grains were transferred from the male parent plants (Serw 1) to the female parent plants, Gemmiza 1 (50 meter distance, at 50 meter distance were recorded the highest percentage of cells containing chromosomal aberrations $\mathbf{2 4 \%}$ ), significant difference was found in chromosome area.

Chromosome length and mitotic index between the isolation distances in all cases, data indicated that differences ranged from the highest score of chromosome area in the variety Serw 1 (male parent plants) to the lowest estimate in the 200 meter, studied isolation distances exhibited variations ranged from the highest score of chromosome length in Serw 1 (male parent plants) to the lowest estimate in the $\mathbf{2 0 0}$ meter distance.

The present isolation distance of 50 meter identification of each of the eight pairs of chromosomes of a idiogram. All chromosomes had centromeric bands and a terminal band in the short arm except the satellite chromosome (chromosome Number 4). Interstitial bands were observed in the short arms.

Chromosomes 1, 2, 3 and 4 each had one prominent interstitial band in their long arm. The satellite chromosome is easy to identify because of the presence of the secondary constriction.

${ }^{1}$ Forage Crops Res. Dept., Field Crops Res. Institute, ARC, Giza, Egypt. Received December 14, 2016, Accepted December 28, 2016
A minstrel degree of minimum recommended isolation distances for Egyptian clover, it includes three minimum distance recommendations :

- Isolation distance of $200 \mathrm{~m}$ for foundation seed.

- Isolation distance of $150 \mathrm{~m}$ for registered seed.

- Isolation distance of $100 \mathrm{~m}$ for certified seed.

Key Words : Egyptian clover - isolation distance - Karyo type - c-Banding chromosome-satellites chromosome (SAT).

\section{INTRODUCTION}

Isolation distance is the minimum separation required between two or more varieties of the same species for the purpose of keeping seed pure. Species in the same genus or family often have similar minimum isolation distance requirements, but occasionally certain varieties within a species may require larger isolation distances. In addition, many environmental factors can affect how far and how effectively pollen can be transferred by wind or by insects.

The definition of pure seed depends on the intended use of it. Home gardeners, seed savers, and commercial seed growers all have different intended uses for their seeds, and therefore different definitions of pure seed are issued.

Commercial seed growers basically have two classes of pure seed: Seed for sale and seed to be used for growing future seed crops unrelated to the direct sale of seed. Large scale commercial seed producers have additional definition of purity as indicated by such terms as "Grower's stock", "Stock Seed" "No. I seed", "Breeder's Seed", "Foundation Seed", "Certified Seed", "Registered Seed". For our purposes, it is not necessary to get into the meaning of these different classes of seed. The take home message for the small scale seed grower is that the definition of "Pure seed" is related to the intended use of the seed: following are some examples of intended use of seed as related to small scale seed production.

The present investigation aimed to obtain the following cytogenetically information:

1) Studing Karyotype characterization will help to get acquainted with the area, length, long arm and short arm chromosome, in addition to determining centromeric index and centromeric position of chromosome for the tested entries. 
2) Determining of mitotic cell division in Egyptian clover varieties as an indication for the adaptability to the Egyptian conditions.

3) Determining frequency of chromosomal aberrations as an indication of the cytological instability in Egyptian clover.

Also, the present study aimed to improve the Cbanding chromosomes technique of Egyptian clover, and develop a standard C-banded karyotype of the Serw I and Gemmiza 1 varieties to determine whether C-banding could be used to identify parental chromosomes in hybrids (optimum isolation distance).

4) The obtained data will be used to define the optimum isolation distance that should be used among varieties where the foundation seed are being propagated using a distinguished character such as the satellites chromosome as a marker in the segregated generations of the polycrossed varieties (Powell et al., 1996; Dalla Rizza et al., 2007; Real et al., 2000; Dias et al., 2008; Santos et al., 2010 and Zhang et al., 2010).

In this investigation we hypothesize that 500 meter (the recommended distance used in producing the foundation seed of such variety) is much more than it needed to produce the isolated distance which should be reduced.

Karyotypic analysis from pachyten chromosomes of Trifolium species are diploid $2 \mathrm{n}=16$, and the basic chromosome number in the majority of the examined species is $\mathrm{X}=8$ (Gold blatt, 1981 and Ellison et al., 2006).

Karyotypic analysis of somatic chromosomes of diploid ssp. has been accomplished through the use of an image analysis system (Bauchau and compbell, 1994).

C-Banding Technique was used to indentify the parental chromosomes of Serw 1, Gemmiza 1 and the resultant generations to confirm for how long the pollen grains of Serw 1 could be transferred under the openpollinated conditions for first generations polycrosses along 50, 100, 150 and 200 meter islation distances. There is only one report of successfully C-banding chromosomes observed mostly centromeric and telomeric bands and only a few interstitial bands (Mariani and Falistocco, 1990).

\section{MATERIALS AND METHODS}

Two varieties of berseem; Gemmiza 1 and Serw 1 were used for cytogenetic analysis, the entries were obtained from the Forage Crops Res. Dept., Field Crops Research Institute, Agricultural Research Center, Egypt and the lab procedures were carried out in Genetics Dept. Faculty of Agric. Alex Univ.

\section{Cytological Studies:}

\section{- Karyotype analysis:}

Chromosomal studies were carried out, based on visible characteristic of the chromosomes. Karyotype analysis is a well established method. It is based on the morphological characteristic of the chromosomes where it is widely used in cytogenetic analysis according to (Fukui and Kakeda, 1994). Imaging by digital camera in the c- metaphase of dividing root tip cells, pretreated with $0.05 \%$ colchicine and analyzed using the video test karyotype software. Measurement of the total length of chromosome (um), long arm, short arm of chromosome, area of chromosome (um), arm ration, cetnromeric position and centromeric index percentage (length of short arm/ length of chromosome) were taken for every chromosome.

From the karyotype analysis of Trifolium genome, the two homologues ( $a$ and $b$ ) of each chromosome pair were judged according to similarities in length of short arm, long arm, total length, arm ratio and centromeric index percentage were calculated ( $a$ and $b$ ) $/ 2$ for each pair was determined and the chromosome pairs were arranged in descending order and were given numbers from 1 to 8 .

\section{Samples preparation:}

Seeds were germinated on moisture filter paper in Petri dishes at $25-30^{\circ} \mathrm{c}$ in an incubator. Root tips were obtained 3days after germination was initiated. The lateral roots were collected of about 1.5 to $2.0 \mathrm{~cm}$ length.

\section{Colchicine treatment:}

The root of $1-1.5 \mathrm{~cm}$ was placed in glass vials containing $2 \mathrm{ml}$ of $0.05 \%$ colchicine for three hours at room temperature or ice water over night.

\section{Fixation and slide preparation:}

A- Fixation was done using ethanol-glacial acetic acid $(3: 1 \mathrm{~V} / \mathrm{V})$ fixative. Those samples were washed thoroughly with water.

B- Samples Flamed by forces and stained by the aceto orcein solution.

C- Stained samples were used for automatic scanning experiments

D- Karyotype analysis was carried out using image Process Analysis System (Video Test- Karyo).

E- The mean measurements in the c-metaphase of fifteen cells for each variety were used to construct the karyotype. 


\section{- Mitotic Index and Chromosomal aberrations:}

For mitotic studies, seeds from two varieties were germinated on moist filter paper on Petri dishes at room temperature in a randomized complete block design experiment with three replications. Each replication comprised three dishes for each entry and each dish contained 30 seeds; actively growing root-tips were cut from the seedlings and fixed in former solution. The aceto-carmine squash technique was used to stain the root-tip cell as described by (Sayed-Ahmed, 1985). Nine prepared slides were used for each variety to determine the frequencies of mitotic index and chromosomal aberrations.

The mitotic index represented the percentage of divided cells to the total cells examined. The percentage of each mitotic phase was calculated by dividing the number of cells in this phase on the total number of dividing cells per each variety. The total number of chromosomal aberrations was estimated in dividing cells. The abnormalities included cells with micronuclei, fragments, laggards, stickiness and binucleate cells.

\section{- C-Banding Chromosomes:}

Seeds were scarified and germinated on filter paper in Petri dishes at room temperature. Root tips were obtained 3 days after germination was initiated, pretreated in an ice bath for $20 \mathrm{~h}$, and fixed in former's fixative $(3: 1 \mathrm{v} / \mathrm{v}, 95 \%$ ethanohglacial acetic acid) for at least $30 \mathrm{~min}$. A modified improved C-banding technique (Hossain, 1985) was utilized to band the chromosomes. A single fixed root tip was placed in a drop of $45 \%$ acetic acid for $2-3$ min on a microscope slide. Dissection of dividing root tip cells was accomplished using sharpened needles under a dissecting microscope. Cells were gently warmed and squashed under a cover slip. The cover slip was removed after freezing the slide with liquid nitrogen. The slides were dried on a hot plate at $55^{\circ} \mathrm{C}-60^{\circ} \mathrm{C}$ for 10-12 min and then treated with $6 \%$ barium hydroxide for $5.5 \mathrm{~min}$ and briefly rinsed in distilled water. After rinsing, the slides were incubated in $2 x \operatorname{SSC}(0.3 \mathrm{M}$ sodium chloride plus $0.03 \mathrm{M}$ trisodium citrate) at $60^{\circ} \mathrm{C}$ for $20 \mathrm{~min}$. Slides were briefly rinsed in distilled water and stained in $7.3 \%$ Giemsa stain (Sigma) phosphate bufler (1 M NaH2 PO4) at $\mathrm{pH} 6.8$ for $30 \mathrm{~min}$. The stained slides were briefly rinsed in distilled water, air dried using a hair dryer for $2 \mathrm{~min}$, and cover slips affixed using Permount. Twenty cells containing wellspread C-banded chromosomes were observed from each accession of the isolation distances. Photomicrographs were taken using a Zeiss Axiophot Microscope using of an image analysis system (Bauchan and Compbell, 1994). Photographs were printed on Agfa multigrade paper using high-contrast filters. The chromosomes from each cell were cut out and homologous pairs were sorted out to develop an idiogram based on length, centromere position, and banding pattern.

The field layout (Fig 1) consisted of 13 faddan and their first generations polycrosses a long 50,100,150 and 200 meter distances from the male parent variety (Serw 1).

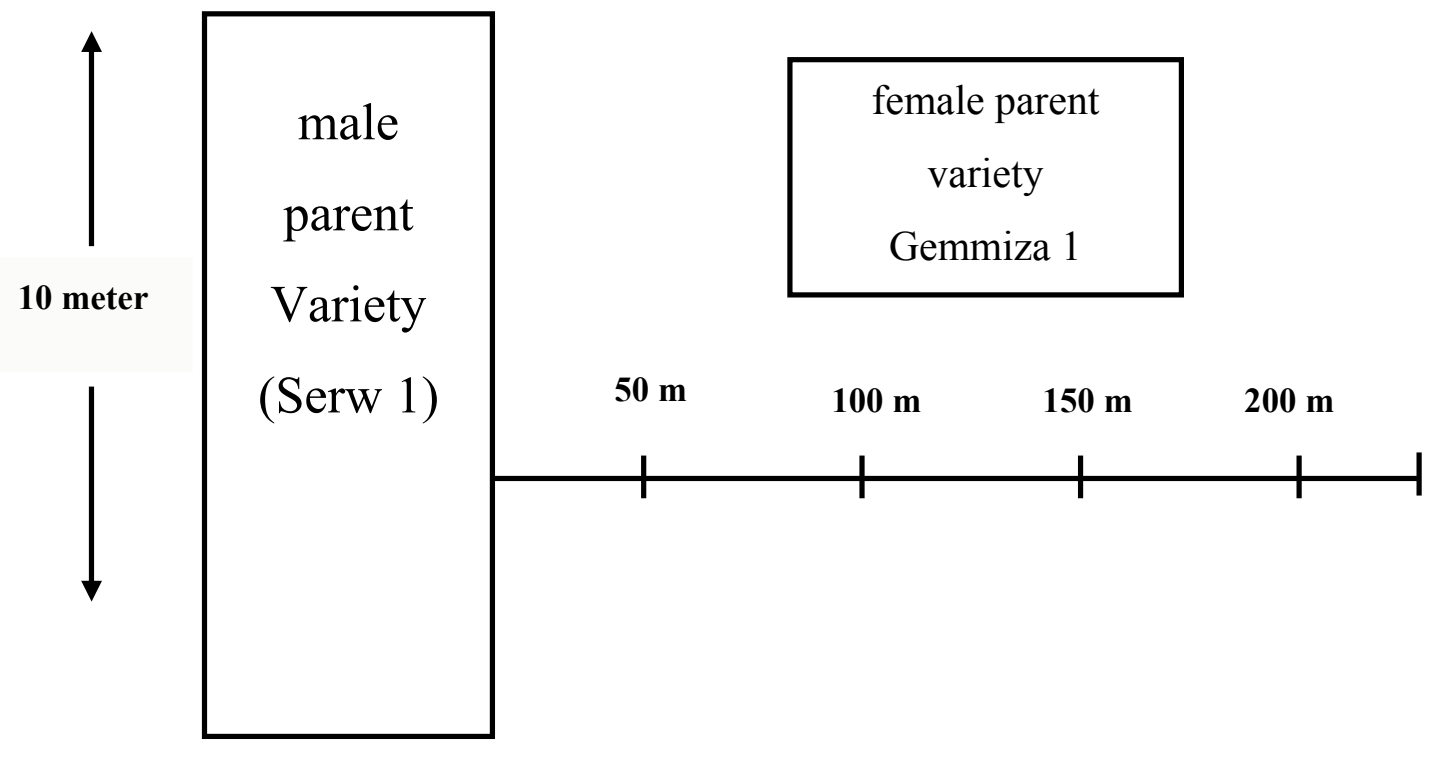

10 meter

Fig. 1. Field idogram of SAT marker at various distances from Egyptian clover 


\section{RESULTS AND DISCUSSION}

\section{Karyotype Characterization:}

Investigating the karyotype analysis of berseem showed that all of studied isolation distances were diploid, with a chromosome number of $2 \mathrm{n}=2 \mathrm{x}=16$, figure (1, 2, 3, 4 and 5). Karyotype analysis includes chromosome area, chromosome length, arm ratio and centromeric index, as well as centromeric position of all isolation distances are presented (Tables 1, 2, 3, 4 and 5) and illustrated in figures (1, 2, 3, 4 and 5).

\section{Mean of karyotype for chromosome area:}

The data obtained from the karyotype, expressed by chromosome area in the isolation distances are given in Table(1). This table showed that the variation in chromosome area among the different isolation distances studied is observable. This variation ranged from the highest value of chromosome area in 100 meter $(6.25 \mathrm{um})$ to its lowest value $(1.57 \mathrm{um})$ in Gemmiza 1 (female parent variety).

The data presented in table (2) show that the chromosome length depended on isolation distances. These differences ranged from the highest score of chromosome length in the male parent variety (Serw 1) (3.67um) to the lowest estimate in isolation distance 200 meter (1.48 um). The maximum chromosome length was $(3.67 \mathrm{um})$ recoded in chromosome 1 of the male parent variety serw 1 , whereas the minimum was (1.48 um) in chromesome 8 of isolation distance 200 meter. The high level of chromosome length indicates more crossing over and recombination (Fayed et al., 1990).

Mean of karyotype for the long arm and short arm chromosome:

The mean karyotype of the long arm and short arm chromosome of the isolation distances of berseem clover are given in Tables (3) and (4).

The isolation distances of berseem showed different trends where the highest chromosome long arm and short arm was exhibited by the male parent variety Serw 1 , while the lowest one was displayed in 200 meter distance. The maximum mean chromosomes long arm and short arm were $1.91 \mathrm{um}$ and $1.85 \mathrm{um}$, respectively, which was recoded in chromosome I of parent variety Serw 1, while the minimum chromosomes were $0.76 \mathrm{um}$ and $0.71 \mathrm{um}$ which was recoded in chromosome 8 and 7 of 200 meter distance and female parent variety; respectively. Similar results were recorded by (Eun et al., 2011) and (Kurata et al., 1978).

Mean of Karyotype for the arm ratio, centromeric index and centromeric position:

The data of mean karyotype, expressed by the arm ratio, centeromeric index and centromeric position in isolation distances are given in Table (5). Date in this table showed the variation in arm ratio between the studied isolation distances. This variation ranged from the highest score of arm ratio in 50 meter distance (1.25 um) chromosome number (4) to its lowest estimate $(0.71 \mathrm{Um})$ in Serw 1 (male parent variety).

Table 1. Mean of chromosome area of the eight chromosomes for the isolation distances of Egyptian clover

\begin{tabular}{lcccccccc}
\hline Isolation distances & \multicolumn{8}{c}{ Average chromosomes area (um) } \\
\cline { 2 - 9 } & $\mathbf{1}$ & $\mathbf{2}$ & $\mathbf{3}$ & $\mathbf{4}$ & $\mathbf{5}$ & $\mathbf{6}$ & $\mathbf{7}$ & $\mathbf{8}$ \\
\hline 50 meter & 4.90 & 4.22 & 3.57 & 4.07 & 2.91 & 2.77 & 2.59 & 2.28 \\
100 meter & 6.25 & 5.79 & 4.96 & 3.69 & 3.41 & 3.17 & 3.05 & 2.53 \\
150 meter & 5.33 & 4.80 & 4.08 & 3.30 & 3.05 & 2.81 & 2.68 & 2.28 \\
200 meter & 4.41 & 3.81 & 3.21 & 2.91 & 2.69 & 2.46 & 2.32 & 2.04 \\
Gemmiza 1 & 5.09 & 4.77 & 3.36 & 3.29 & 2.35 & 2.33 & 1.57 & 2.04 \\
Serw 1 & 5.11 & 4.84 & 3.75 & 3.64 & 2.81 & 2.93 & 2.17 & 2.37 \\
\hline
\end{tabular}

Mean of karyotype for chromosome length at isolation distances of berseem.

Table 2. Mean chromosome length of the eight chromosomes for the isolation distances of berseem

\begin{tabular}{lcccccccc}
\hline Isolation distances & \multicolumn{7}{c}{ Average chromosomes total length (um) } \\
\cline { 2 - 8 } & $\mathbf{1}$ & $\mathbf{2}$ & $\mathbf{3}$ & $\mathbf{4}$ & $\mathbf{5}$ & $\mathbf{6}$ & $\mathbf{7}$ & $\mathbf{8}$ \\
\hline 50 meter & 3.60 & 3.19 & 2.79 & 2.94 & 2.33 & 2.25 & 2.14 & 1.86 \\
100 meter & 3.51 & 3.09 & 2.65 & 2.46 & 2.32 & 2.17 & 2.05 & 1.73 \\
150 meter & 2.93 & 2.64 & 2.34 & 2.18 & 2.02 & 1.92 & 1.82 & 1.60 \\
200 meter & 2.35 & 2.19 & 2.04 & 1.90 & 1.72 & 1.67 & 1.60 & 1.48 \\
Gemmiza 1(female parent) & 3.40 & 3.52 & 2.49 & 2.82 & 2.44 & 2.34 & 1.58 & 1.78 \\
Serw 1 (male parent) & 3.67 & 3.67 & 2.65 & 2.75 & 2.41 & 2.37 & 1.62 & 1.78 \\
\hline
\end{tabular}


Table 3. Mean chromosome long arm of the eight chromosomes for the isolation distances of berseem

\begin{tabular}{lcccccccc}
\hline Isolation distances & \multicolumn{8}{c}{ Average chromosomes long arm (um) } \\
\cline { 2 - 8 } & $\mathbf{1}$ & $\mathbf{2}$ & $\mathbf{3}$ & $\mathbf{4}$ & $\mathbf{5}$ & $\mathbf{6}$ & $\mathbf{7}$ & $\mathbf{8}$ \\
\hline 50 meter & 1.82 & 1.75 & 1.49 & 1.36 & 1.21 & 1.20 & 1.12 & 0.95 \\
100 meter & 1.90 & 1.65 & 1.37 & 1.25 & 1.18 & 1.15 & 1.05 & 0.89 \\
150 meter & 1.54 & 1.41 & 1.22 & 1.15 & 1.03 & 1.01 & 0.94 & 0.82 \\
200 meter & 1.19 & 1.17 & 1.07 & 1.05 & 0.88 & 0.86 & 0.83 & 0.76 \\
Gemmiza 1(female parent) & 1.74 & 1.78 & 1.35 & 1.42 & 1.29 & 1.28 & 0.87 & 1.04 \\
Serw 1(male parent) & 1.91 & 1.82 & 1.43 & 1.41 & 1.24 & 1.28 & 0.87 & 1.04 \\
\hline
\end{tabular}

Table 4. Mean chromosome short arm of the eight chromosomes for the isolation distances of berseem

\begin{tabular}{lcccccccc}
\hline Isolation distances & \multicolumn{7}{c}{ Average chromosomes short arm (um) } \\
\cline { 2 - 8 } & $\mathbf{1}$ & $\mathbf{2}$ & $\mathbf{3}$ & $\mathbf{4}$ & $\mathbf{5}$ & $\mathbf{6}$ & $\mathbf{7}$ & $\mathbf{8}$ \\
\hline 50 meter & 1.78 & 1.44 & 1.30 & 1.64 & 1.12 & 1.05 & 1.02 & 0.91 \\
100 meter & 1.61 & 1.44 & 1.28 & 1.21 & 1.14 & 1.02 & 1.00 & 0.84 \\
150 meter & 1.38 & 1.23 & 1.76 & 1.03 & 0.99 & 0.91 & 0.88 & 0.78 \\
200 meter & 1.16 & 1.02 & 0.97 & 0.85 & 0.84 & 0.81 & 0.77 & 0.72 \\
Gemmiza 1(female parent) & 1.66 & 1.74 & 1.14 & 1.40 & 1.15 & 1.06 & 0.71 & 0.74 \\
Serw 1(male parent) & 1.76 & 1.85 & 1.22 & 1.34 & 1.17 & 1.09 & 0.75 & 0.74 \\
\hline
\end{tabular}

The maximum mean centromeric index was $(57.45 \%)$ recorded in chromosome 1 of Serw 1 (male parent variety), while the minimum was $45.75 \%$ recorded in chromosome 1 of 100 meter distance. The centromeric position was metacentric in all isolation distances.

The diploid number of the chromosome was found to be $2 n=16(x=8)$. All chromosome are metacenteric and satellites chromosome were observed in the karyotype analysis in 50 meter distance chromosome number 4 and found in Serw 1 (male parent variety) chromosomes number 2 and 3 (Schifino et al., 1988).

\section{Chromosomal aberrations:}

The data presented in Table (6) showed that, the percentage of cells containing either micronuclei or chromosomal aberrations in mitotic divisions depended on the isolation distances examined These differences ranged from the highest score of chromosomal aberrations in the 50 meter isolation distance and Serw 1 (male parent variety) to Zero estimates in $100 \mathrm{~m}, 150 \mathrm{~m}$ and $200 \mathrm{~m}$. The types of chromosomal aberrations observed were fragments, stickiness, binucleate cell, laggards and micronuclei.

The occurrence of low or high chromosomal aberrations in the studied isolation distances could be explained on the basis of differences in the rate of DNA repair mechanism induced by genotype. The rate of such repair may depend mainly on the genotype of isolation distances.

In this respect, Suzanne (2008) reported that the chromosome aberrations are produced as a result of repair of damaged DNA.
Karyotypic Analysis of C-Banded Chromosomes:

50 meter isolation distance C-banded chromosomes have bands only at the centromeric region with the exception of the satellited (SAT) chromosome (chromosome 4) which also has a large band at the nucleolar organizer region (NOR) (Fig. 7).

An idiogram of a standard karyotype is presented in figure. A brief description of the c-banding pattern is as follows:

Chromosome I: The Largest chromosome without an NOR is submetacentric and has a terminal band on the short arm, in addition to the interstitial band is located on the long arm.

Chromosome 2: A submetacentric chromosome with a large telometric band on the short arm and two interstitial bands located on each arm of the chromosome.

Chromosome 3: A submetacentric chromosome with on terminal band on the short arm; the interstitial band on the long arm is located near the centromere.

Chromosome 4: The SAT Chromosome that is submetacentric with two bands flanked by the NOR and the centromere. On the short arm. a terminal band is located on the long arm of the chromosome.

Chromosome 5: A submetacentric chromosome with an interstitial band and terminal band is located on the short arm of the chromosome.

Chromosome 6: A short metacentric chromesome with a terminal band on the short arm. 
Chromosome 7: A short metcentric chromosome with only centromeric bands and a telomeric band on the short arm of the chromosome with no interstitial bands.

Chromosome 8: A short metacentric chromosome with interstitial band on the long arm of chromosome

- Serw I parent variety C-Banded Chromosomes have bands at the centromeric region, with the exception of the satellite (SAT) Chromosome (Chromosome $2,3)$.

An idiogram of a standard karyotype is presented in Figure (8) A brief description of the C-Banding pattern is as follows:

Chromosome I: The largest chromosome without an NOR is Metacentric and has a terminal band on the short arm, in addition to the interstitial band is located on the long arm.

Chromosome 2: A submetacentric chromosome with a large band at the nucleolar organizer region (NOR). But occasionally a secondary constriction can be found on the long arm of the chromosome.

Chromosome 3: A submetacentric chromosome with a large band at the nucleolar organizer region (NOR). But occasionally a secondary constriction can be found on the long arm of the chromosome.

Chromosome 4: A submetacentric Chromosome with a terminal on the long arm and in addition to the interestital band is located on the short arm.

Chromosome 5: A submetacentric chromosome with an interstitial band and terminal band is located on the short arm of the chromosome.

Chromosome 6: A submetacentric chromosome with a terminal band on the short arm.

Chromosome 7: A submetacentric chromosome with a terminal band and interstitial band on the short arm.

Chromosome 8: Acrocentric chromosome with a interstitial band on the long arm and terminal band on the short arm.

- Gemmiza 1 mother variety C-Banded chromosomes have bands at the centromeric region without an nucleolar organizer region (NOR) and without satellite chromosome (SAT) (Fig. 9).

- An idiogram of a standard karyotype is presented in Figure (9) Abrief description of the c-banding pattern is as follows:

- Gemmiza 1 mother variety C-Banded chromosomes have bands at the centromeric region without an nucleolar organizer region (NOR) and without satellite chromosome (SAT) (Fig. 9).
- An idiogram of a standard karyotype is presented in Figure (9) Abrief description of the c-banding pattern is as follows:

Chromosome 1: The largest chromosome has a terminal bands located on each arm of the chromosome, a large interstitial band is located near the centromere on the long arm.

Chromosome 2: A submetacentric chromosome with on terminal band on the short arm two interstitial band located on each arm of the chromosome.

Chromosome 3: A submetacentric chromosome with on terminal band on the short arm and two interstitial bands located on each arm of the chromosome.

Chromosome 4: A submetacentric chromosome with on interstitial band located on the long arm of the chromosome.

Chromosome 5: A short metacentric chromosome with on interstitial band located on the long arm of the chromosome.

Chromosome 6: Ashort metacentric chromosome with on interstitial band located on the short arm of the chrome some.

Chromosome 7: A short metacentric chromosome with on interstitial band located on the long arm.

Chromosome 8: Ashort metacentric chromosome with two interstitial bands located on each arm of the chromosome.

Due the distinctive differences in the banding pattern of the 50 meter isolation distance, serw 1 (parent variety) and Gemmiza 1 mother variety having multiple bands and 50 meter isolation distance having AST chromosome with two bands flanked by the NOR and the centromere.

The SAT chromosome is easy to identify because of the presence of the secondary constriction and also because of the large terminal band on the long arm of the chromosome.

The differences we observed in the banding patterns of the 50 meter isolation distance, serw 1 (parent variety) and Gemmiza 1 (Mother variety) makes it possible to identify parental chromosome of serw 1 (parent variety) in the 50 meter isolation distance (hybrid).

Also, the obtained results in the USA, general Clover Standards for Field of Less than 2 ha required an isolation distance of $274 \mathrm{~m}$ for Foundation seed (maximum $0.1 \%$ contamination with other varieties permitted), 


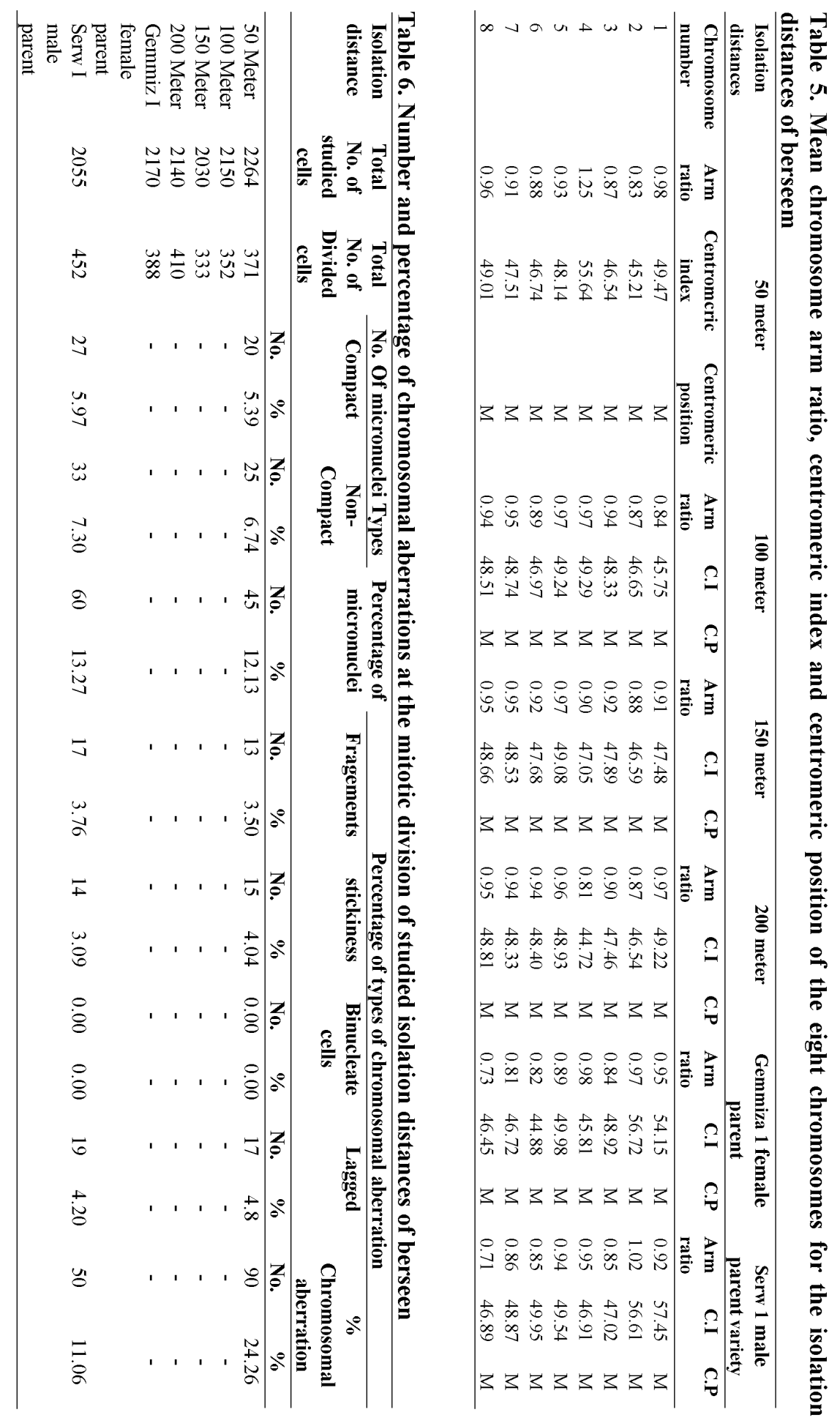




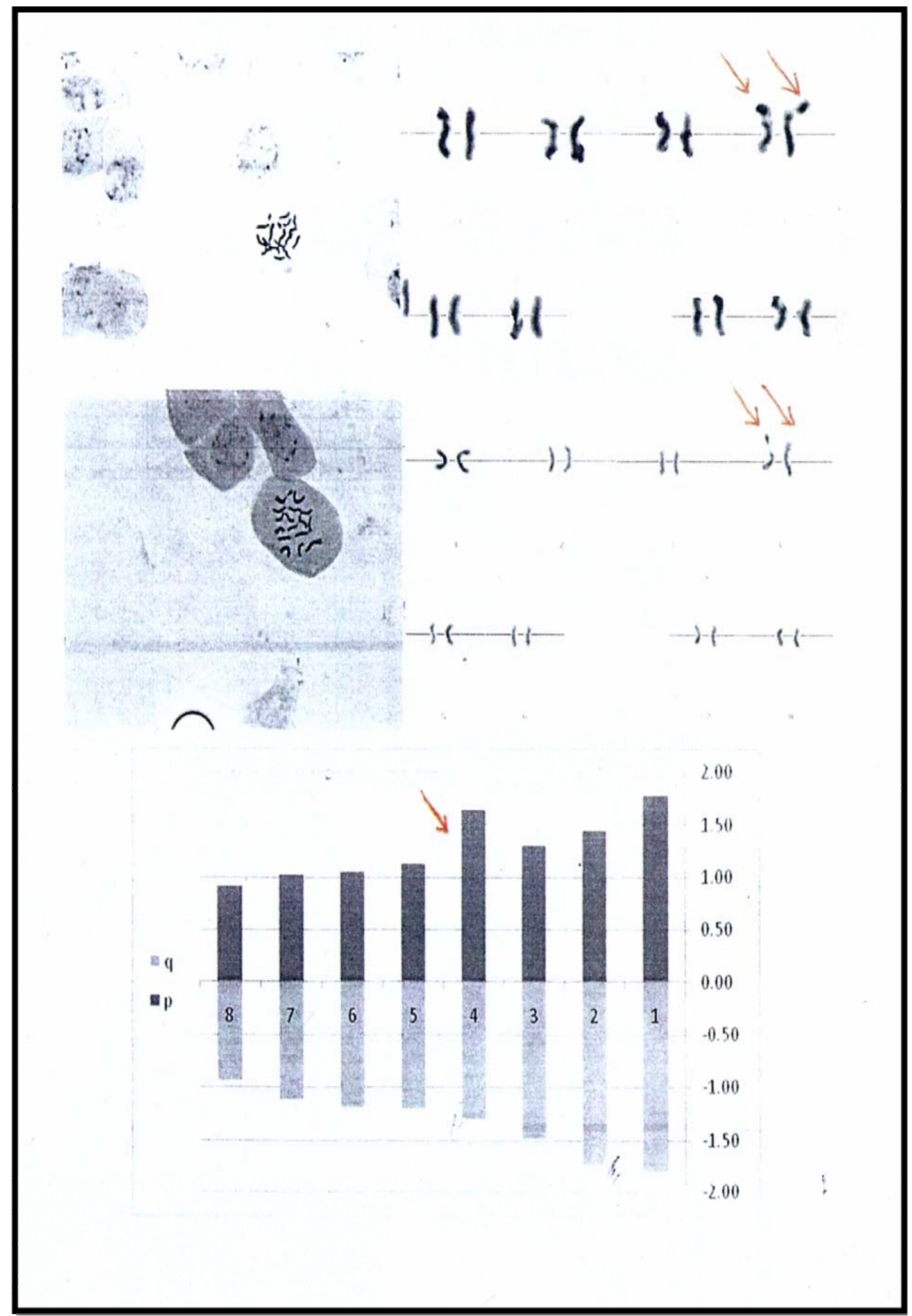

Fig. 1. Metaphase and Karyotype of chromosome of 50 meter isolation distance 


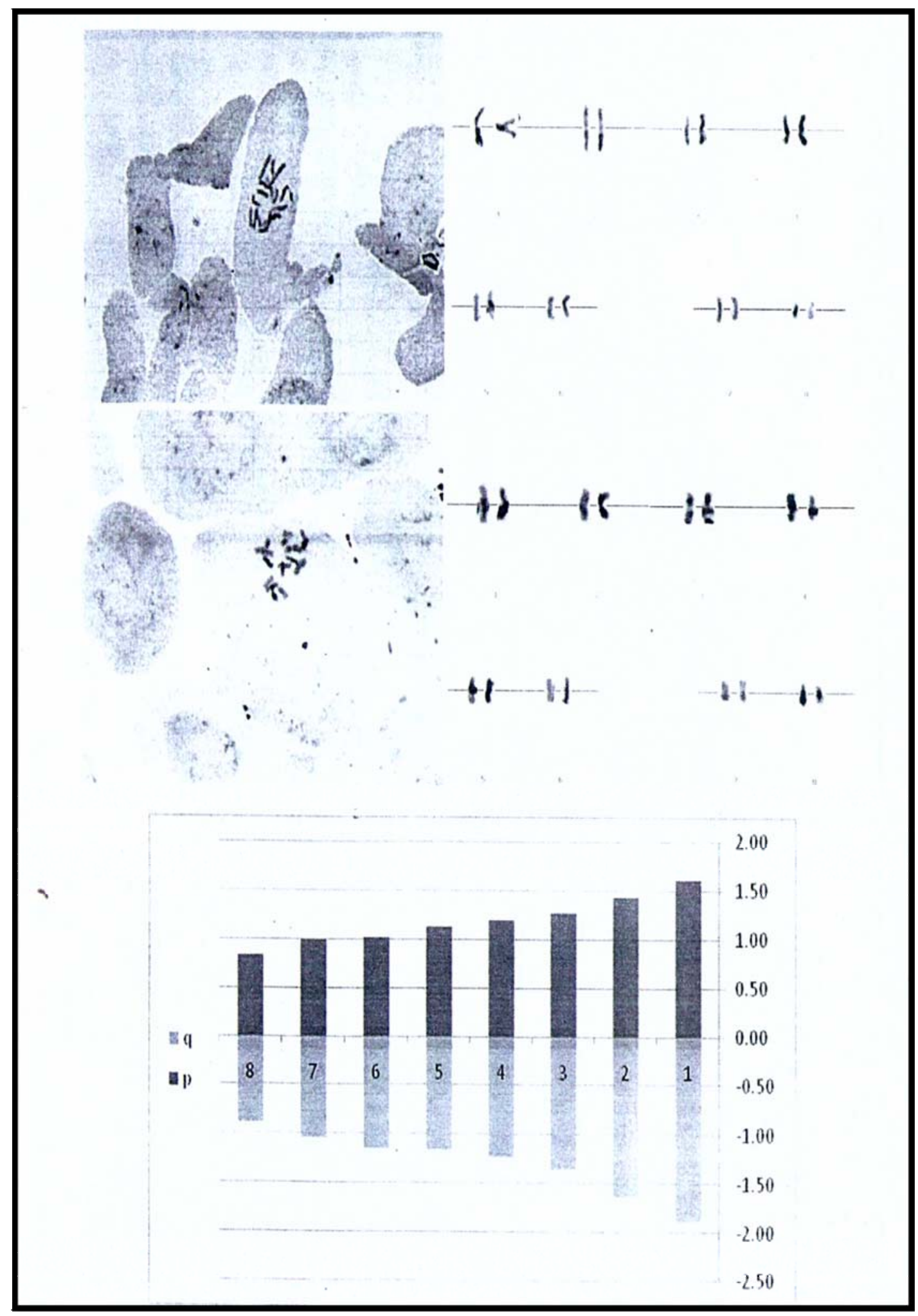

Fig. 2. Metaphase and Karyotype of Chromosome of 100 Meter Isolation distance 


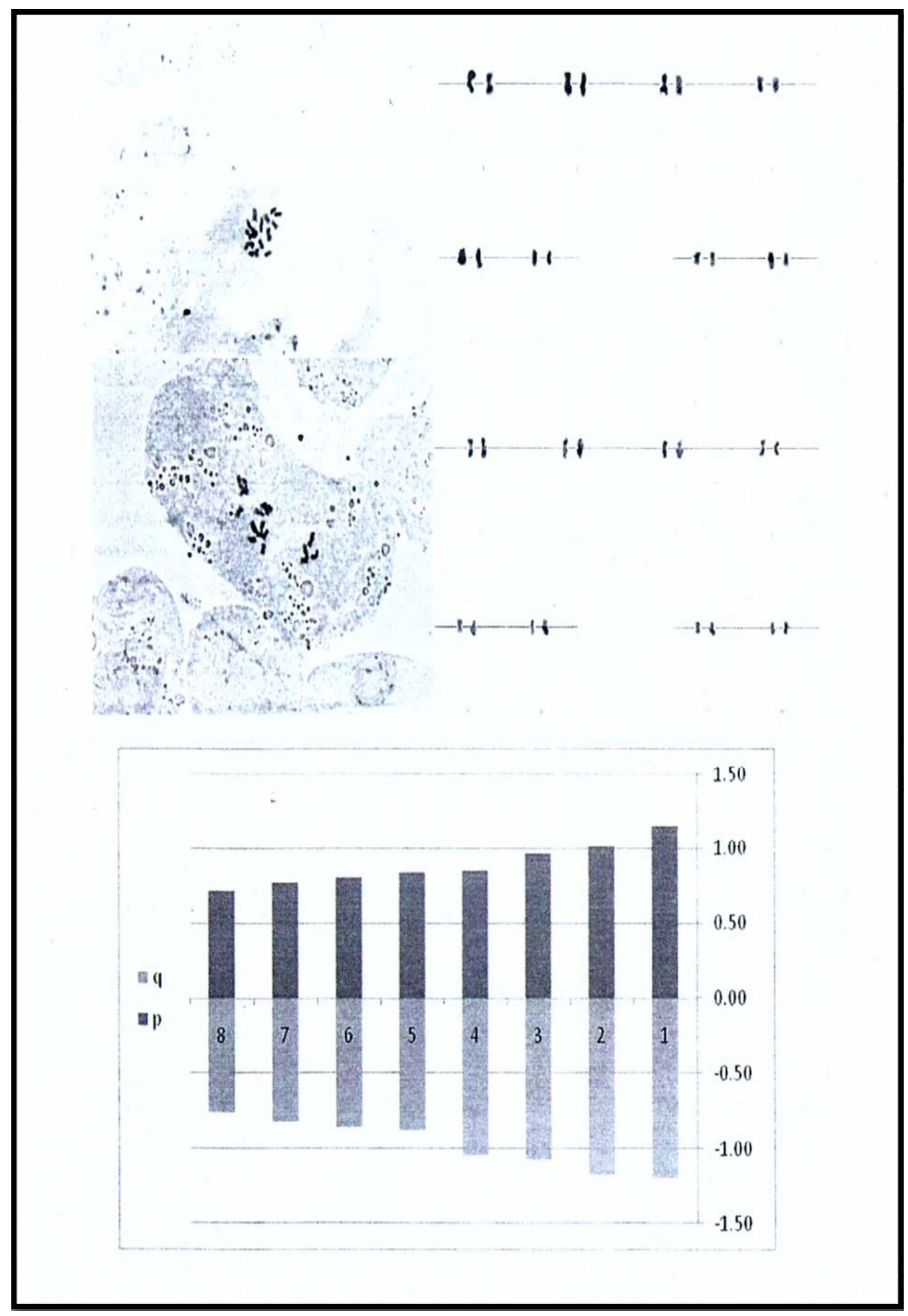

Fig. 3. Metaphase and Karyotype of Chromosome of 150 Meter Isolation distance 


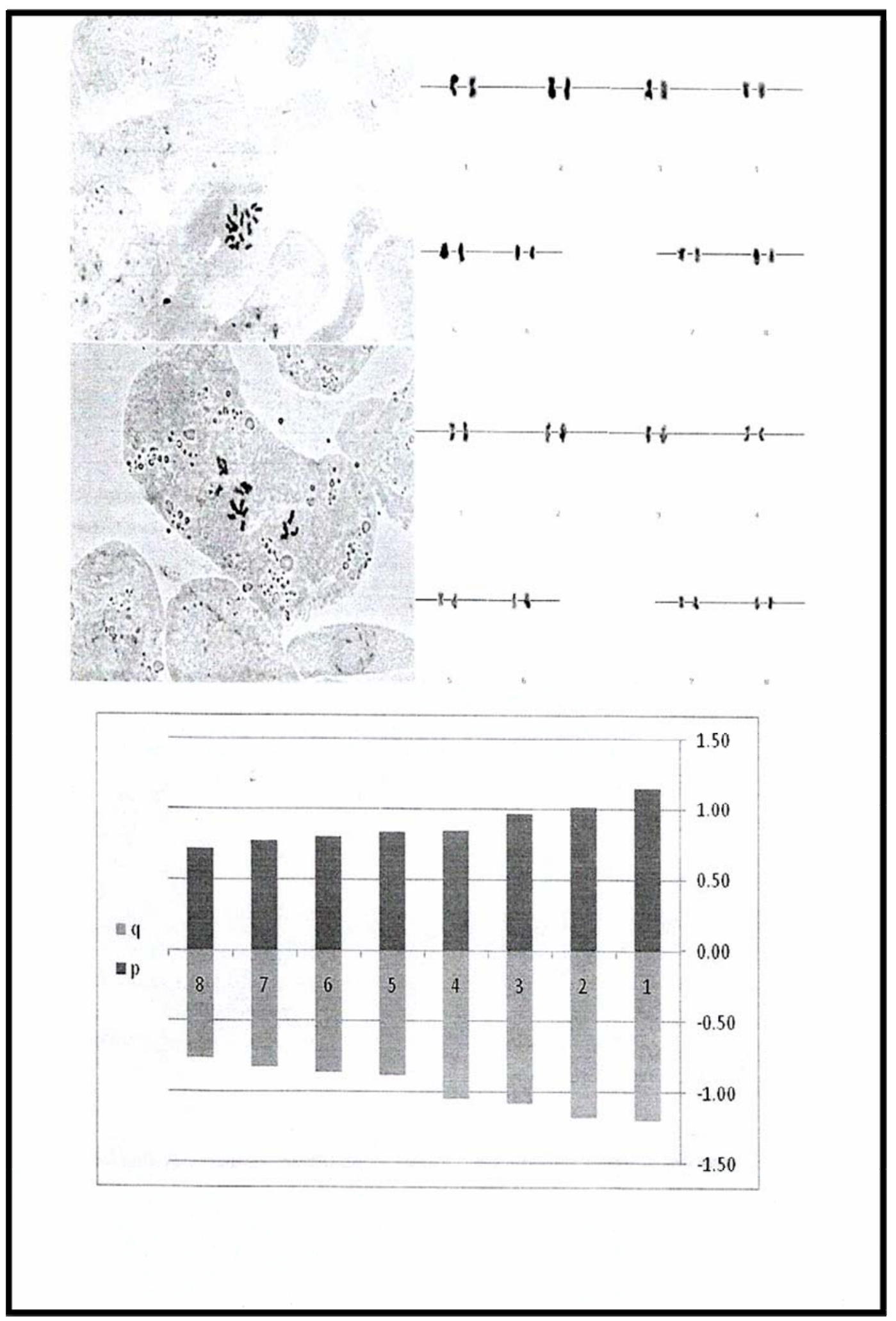

Fig. 4. Metaphase and Karyotype of Chromosome of 200 Meter Isolation distance 


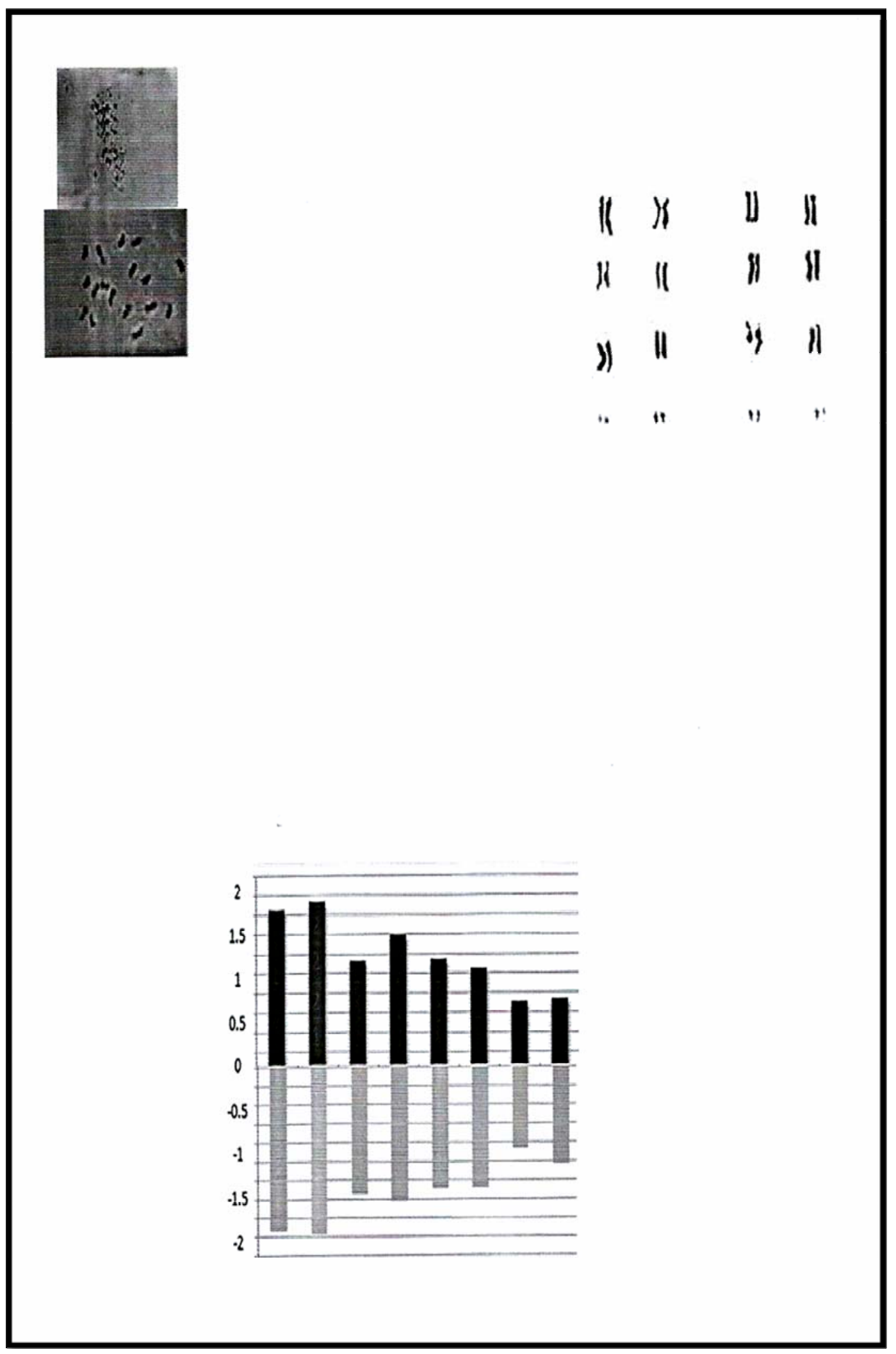

Fig. 5. Metaphese and Karyotypes of Chromosome of mother variety Gemmiza 1 


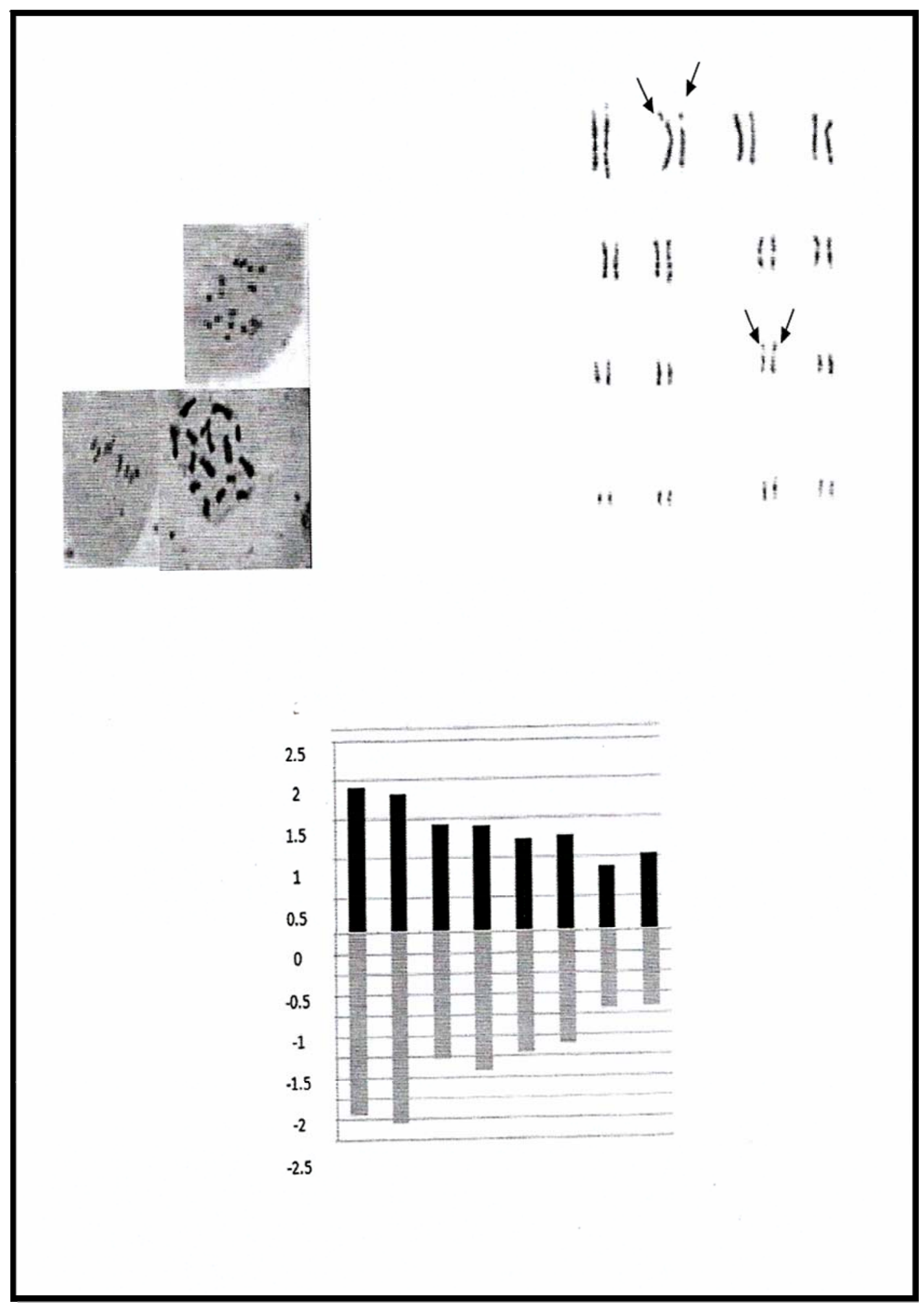

Fig. 6. Metaphese and Karyotypes of Chromosome of parent variety serw 1 


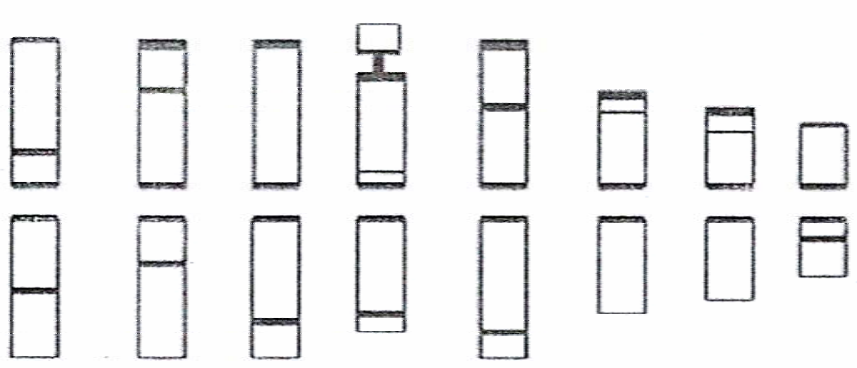

$1 \quad 2 \quad 3 \quad 4 \quad 5 \quad 6 \quad 7 \quad 8$

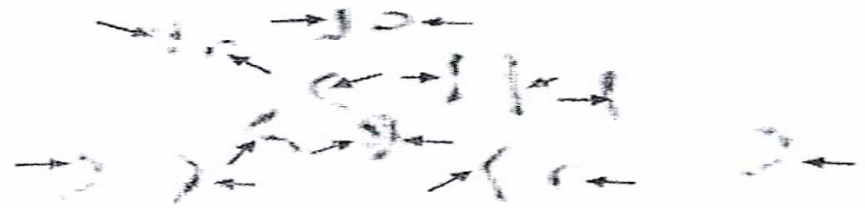

Fig. 7. Idiogram of C-banded chromosomes of 50meter isolation distance

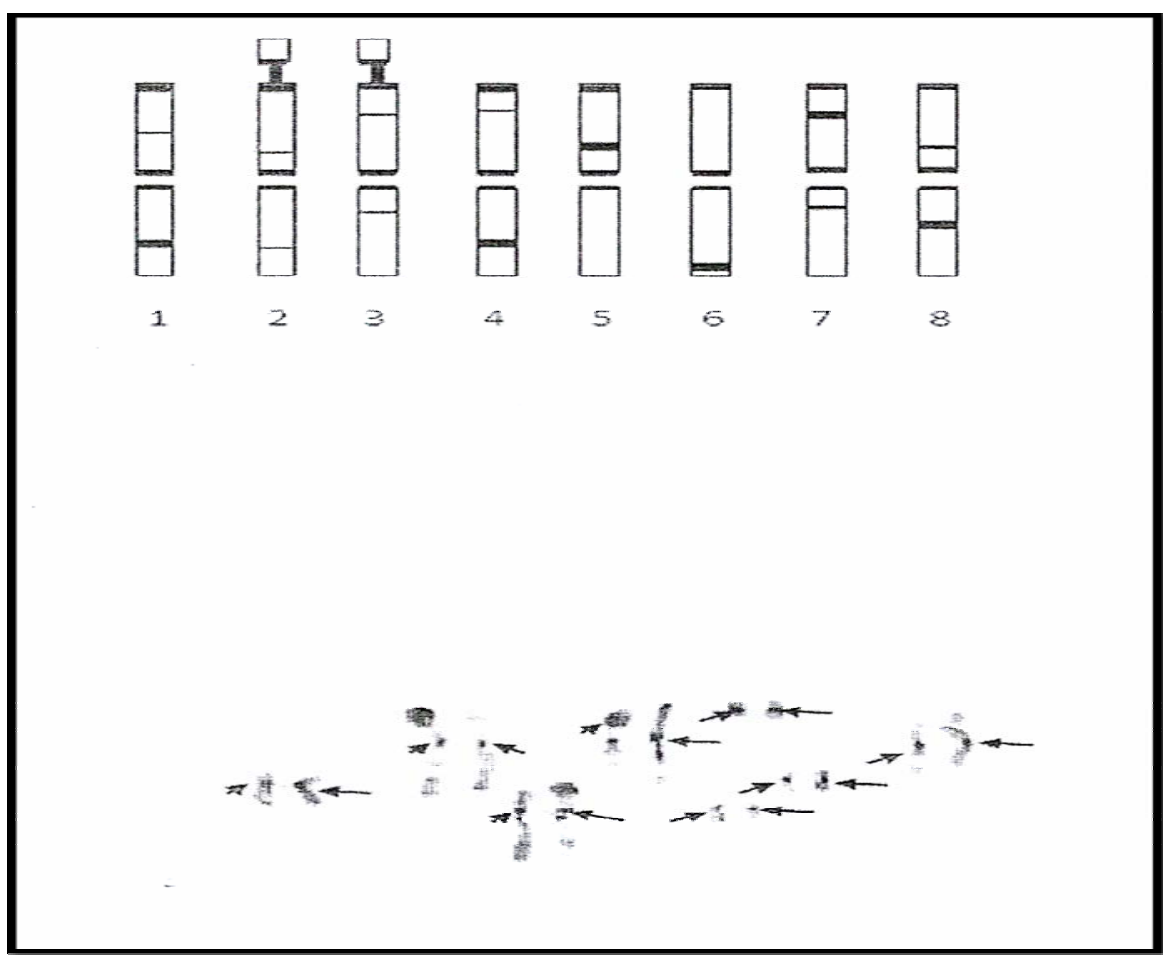

Fig. 8. Idiogram of C-banded chromosomes of Serw 1 (Parent Variety) 


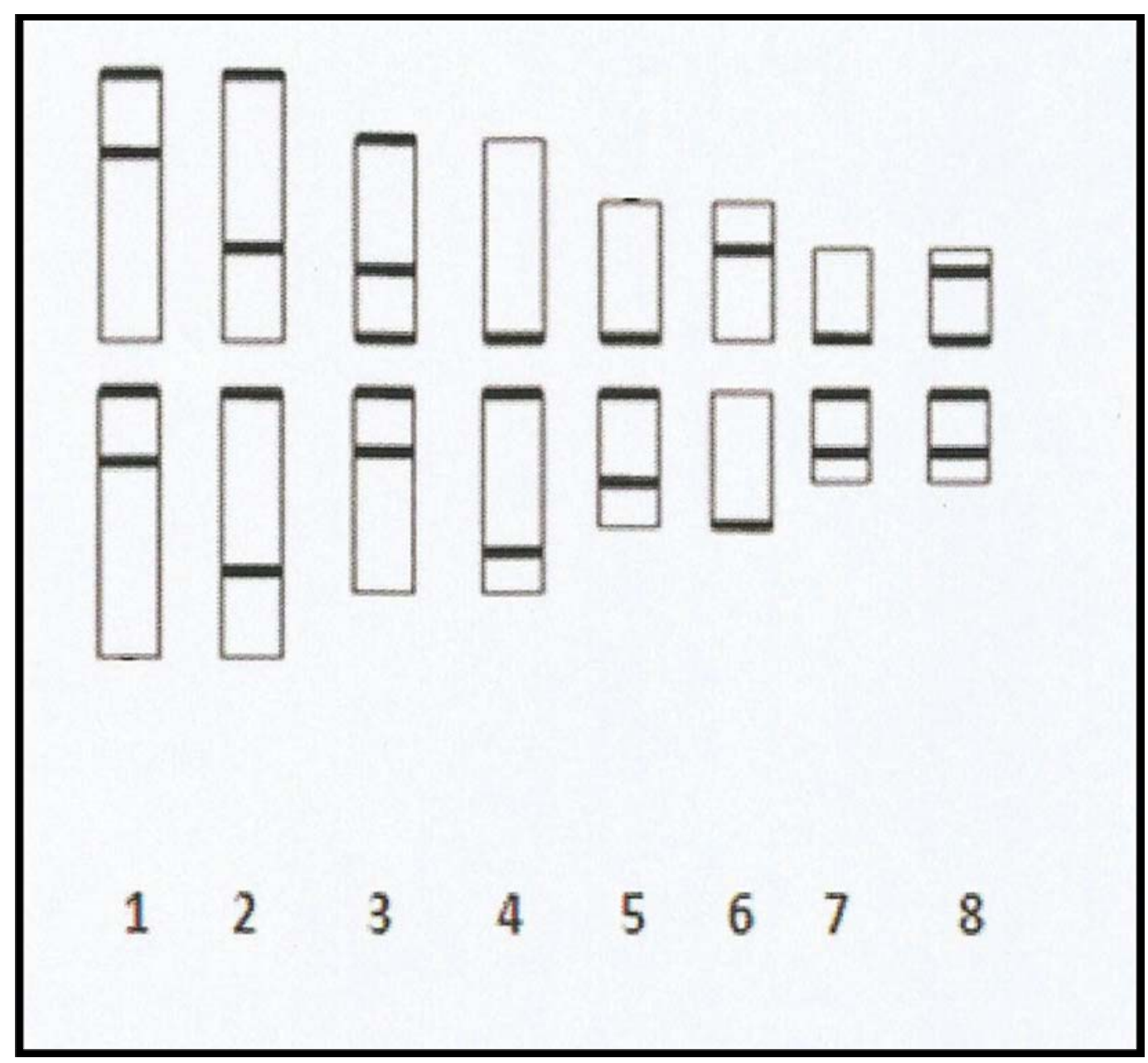

Fig. 9. Idiogram of C-banded chromosomes of Gemmiza1 (Mother orgenetype)

$137 \mathrm{~m}$ for registered seed (maximum 1.0\% contamination with other varieties permitted) and $50 \mathrm{~m}$ for certified seed (maximum $1.0 \%$ contamination with other varieties permitted) (Association of official seed certifying Agencies 2003).

Otherwise, in Europe, an isolation distance of $200 \mathrm{~m}$ is required (for fields of 2 ha or less) basic legume seed.

Furthermore, OECD standards for Legumes are consistent with south Australian white clover standards (smith and Baxter 2002) and New Zeland seed standards for legume (MAF Biosecurity 2007). Our detected isolation distance with $50 \mathrm{~m}$ was minimum of which detected by Pankiw (1975), Present isolation distance of $183 \mathrm{~m}$, with a minimum of contaminant bloom in the area, be retained to the smaller acreages of foundation seed.

\section{REFERENCES}

Association of Afficial Seed Certifying Agencies 2003. Operational Procedures, Crop Standards and Service Programs Publication. AOSCA Idaho.pp1-287.

Bauchan, G.R., and T.A. Campbell. 1994. Use of An Image Analysis System to Karyotype Diploid Alfalfa (Medicago Sativa L.) J. Hered 85 : 18-22.

Dalla Rizza, M., D.Real, R.Reyno, V.Porro, J.Burgueno, E.Errico, K.H.Quesenberry. 2007. Genetic Diversity and DNA Content of Three South American and Three Eurasiatic Trifolium Species. Genetics and Molecular Biology 30 : 1118-1124.

Dias, P.M.B., B.Julier, J.P.Sampoux, P.Barre, M.Dall' Agnol. 2008. Genetic Diversity in Red Clover (Trifolium Pratense L.) Revealed by Morphological and Microsatellite, (SSR) Markers. Euphytica 160 : 189-205.

Ellison, N.W., A. Liston, J.J. Steiner, W.M. Williams and N.I.Taylor. 2006. Molecular Phylogenetics of the Clover Genus (Trifolium Leguminosae). Molecular Phylogenetics and Evolution $39: 688-705$. 
Eun, J., B.Kwany, H.Hyun. 2011. Karyotype Analyses of arice Cultivar "Nakdong" and Its Four Genetically Modified Events by Conventional Staining and Fluorescences in Situ Hybridization. Kor. J. Breed Sci. 43(4) : 184-191.

Fayed, A.H., A.S.Mandour, and M.A. Ismail. 1990. Variation in Chiasma Frequency in Various Types of Vicia Faba L. Indian. J. Genet. PI. Breed. 14 : 640-646.

Fukui, K. and K.Kakeda. 1994. Dynamic Change in the Morphology of Barley Chromosome During the Mitotic Metaphase Stage. The Japanese. J. of Genetics, 69(5) : $545-554$.

Goldblatt, P. 1981. Cytology and the Phylogeny of Leguminosae. In : Poihill, RM and Raven PH (eds), Advances in Legume Systematics, Vol. 2 : $427-464$. Royal Botanic Gardens, Kew.

Hossain, M.A. 1985. An Improved Giemsa C-Banding Technique - Bangladesh. J. Bot 14 : 37-40.

Kurata, N., T.Omura. 1978. Karyotype Analysis In Rice A new Method for Identifying all Chromosome Pairs. Japan J. Genetics : 251-255.

MAF Biosecurity, N.Z. 2007. Seed field production standards. www.biosecurity.govt.nz/fiels/regs/stds/seed-fieldproduction-standards.pdf.

Mariani, A. and E. Folistocco. 1990. Chromosome Studies In $2 \mathrm{n}=14$ and $2 \mathrm{n}=16$ Types of Medicago Murex. Genome $33: 159-163$.

Pankiw, P. 1975. Effects of Isolation distance Border Removal on contamination in Red Clover Seed Production. Canadian Journal of plant science, 55(2) : 391-395, 10.4141 in cjps $75-062$.
Powell, W. G.C.Machray., J.Provan. 1996. Polymorphism Revealed by Simple sequence Repeats - Trends in Plant Science $1: 215-222$.

Real, D., M.Dalla Rizza., R.Reyno., K.H. Quesenberry. 2007. Breeding System of the aerial flowers in an amphicarpic clover species : Trifolium polymorphum. Crop Science 47 : 1401-1406.

Santos, C.A.F., V.R.Oliveira., M.A.Rodrigues., H.L.C. Ribeiro. 2010. Molecular Characterization of onion cultivars using microsatellite markers - pesquisa Agropecuaria Brasileira 45 : 49-55 (in Portuguese, with abstract in English).

Sayed. Ahmed, M.S. 1985. Genetical and Cytological Studies in Broad Bean (Vicia Faba L.). M.SC. Thesis, Fac. Agric. Zagazig University.

Schifino, Wittmann, M.T., Moraes, Fernandes, M.I.B. 1988 Chromosome Numbers, Karyotypes and Meiotic Behavior of Populations of Some Trifolium (Leguminosae) Species. Brazilian Journal of Genetis $11: 379-390$.

Smith, P., and L.Baxter. 2002. South Asutralian seed certification scheme. Procedures and Standards Manual. Seed services, primary Industries and Resources south Australia, Available online at www.ruralsoutions.sa.gov.au/data/assets/ pdf/0005/43349/ seeds.manual.pdf.

Suzanne, C. 2008. DNA Damage and Repair : Mechanisms for Maintaining DNA Integrity. Nature Education 1(1) : 103.

Zhang, X., Y.Zhang., R.Yan., J.Han., F.Hong., J.H.Wang., K.Cao. 2010. Genetic Variation of White Clover (Trifolium Repens L.) Collections from China Detected by Morphological Traits, RAPD and SSR, AFRican Journal of Biotechnology 9: 303-304. 


\section{المالضص العرى}

\section{لمتخدلم قنية التوصيف الحزمي للكرووسومل C- banding chromosome وتحللى الهيئة} الكرومسوميه Karyotypic analysis لتحسيد مسلك العزل في البوسيم المصري

عبد العزيزطلعت بندق،شيرين محمد النحراوي

- لطاهرت فنية Karyotypic analysis وجود فروق بين مسافت العزل من حيث طول الكروموسوم، طول فيلة

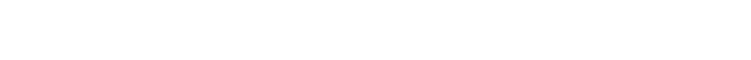
الكروموسوم والشطط الميتوزي.

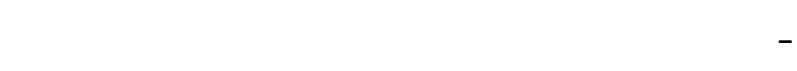

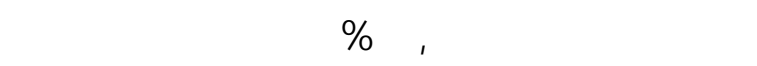

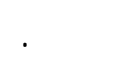

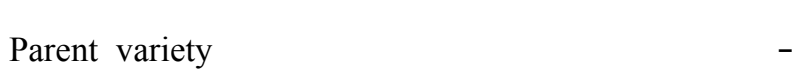

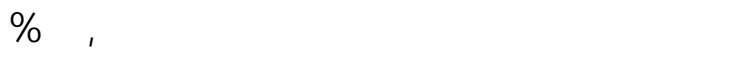

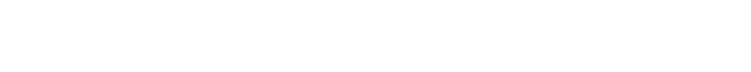
الإنحرافلت الكروموسومية.

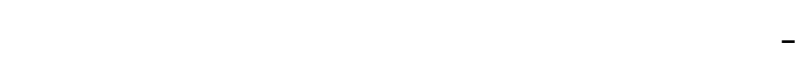

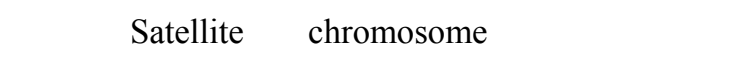
Parent الكروموسوم رقم ع وأيضا الصف سروبة

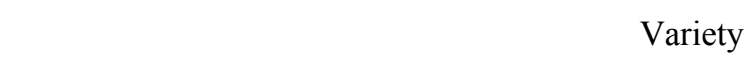
الكروموسوم رقم با، ب على التوالي. - لظٔلهرت الدرلسة الثشابة في الهيئة الكروموسومية بين

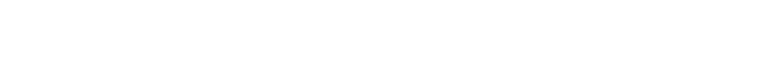
من خلال وجود Satellite chromosome كعلامة مميزة للهيئة الكروموسومية للك منهما. - أظهرت الدرلسة أن الصف جميزة المستخدم كلم لا لا لأل يحتوي Satellites chromosomes - حدوث الخطا الورلثي بين مسافة العزل ·0 متر والصفسروا المستخم كئب.
في هذا البهث مت لمتخدلم قنية التوصف الحزمي للكروموسومات C-banding chromosome والتوصيف الكروموسومي في درلمة مسافلت العزل في البرويسيم المصري وكافت المسلفت المستخمة في الدرلسة هي: -مسافة العزل · مترمن صف جميزة اكلم.

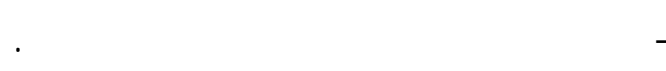
-مسافة العزل • 10 مترمن صف جميزة اكلم.

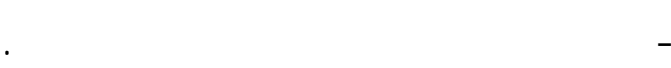
وقم إستخدلم الصفسرووا كئب. Karyotypic يعتمد توصيف المجموعة الكروموسومية analysis الكروموسوم، طول الذراع الطويل والقصير للكروموسوه

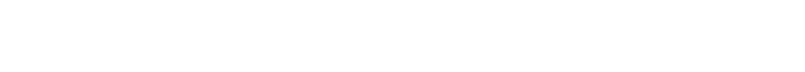
ودرلسة الشطا الميتوزي والإنحرافلت الكروموسومية والطرز المختلفة للإنحرافلت في مسافلت العزل المختلفة. كذك لمتخدلم التوصف الحزaي للكروموسومات Parental فورض تعريف C-banding chromosome chromosome في مسافلت العزل المختلفة من خلا درئل فرية

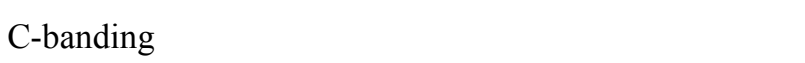
pattern والني تعتمد على التوصف البياني للكروموسوملت النيات Idiogram المسافت العزل المختلفة. وذك بهرف تحديد مسلف العزل في البوسيم المصري

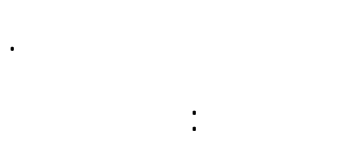




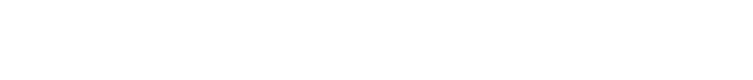

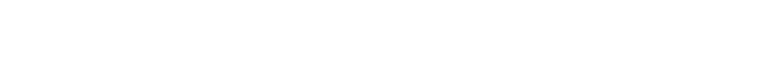
الكروموسومية.

في ضوء النتائج المتحصل عليها توصي الدرلمة بأن

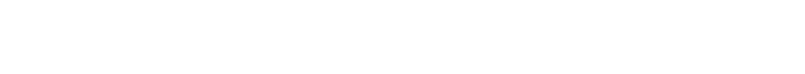
تحت الظروف المصرية على النحو التالي: - درجة الإنتاج نقاوي الأسلس مسافة العزل المقترحة لهالي r. . بمتر الانتاح.

- درجة الإنتاج قاوي المسل مسافة العزل المقترحة لها

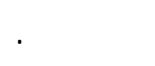

- درجة الإنتاج نقاوي المتتمد مسافة العزل المقترحة لها

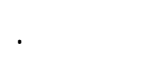

الكلمك الدالة: - الببسيم المصري- مسلفة العزلKaryotype - C-banding chromosome - Satellite chromosome (SAT)

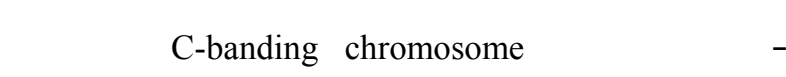
التوصف البيلني للكروموسومات Idiogram وجود

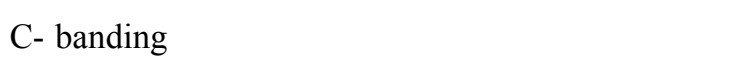

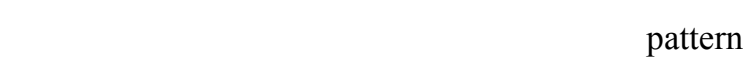
المستخدم كلب والصف جميزة المستخدم المكلم.

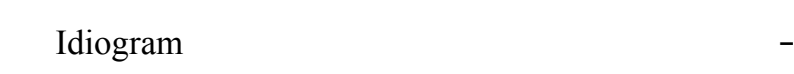

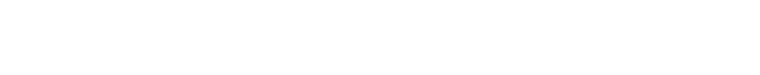
الكروموسومية(SAT 4) على الكروموسوم رقمع وأيضا الصف سرووا المستخدم كلب على الكروموسوم رقو

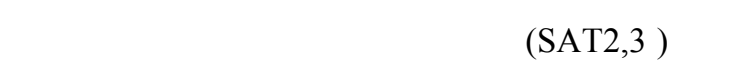
يحتوي على التوليع الكروموسومية. كذلك إحتواء مكافة العزل م متر على مطقة مظم النوية (NOR)

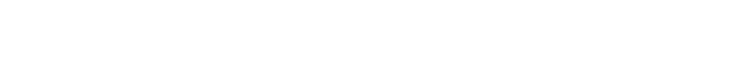
جميزة I المستخدم كلم لا يحتوي على (NOR).

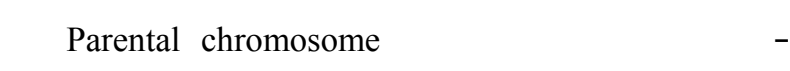
مسافة العزل •0 متر بالمقارنة ببالقي مسافلت العزل. 